Article

\title{
Strategies for Improved Yield and Water Use Efficiency of Lettuce (Lactuca sativa L.) through Simplified Soilless Cultivation under Semi-Arid Climate
}

\author{
Nicola Michelon ${ }^{1}$, Giuseppina Pennisi ${ }^{1}{ }^{1}$, Nang Ohn Myint ${ }^{2}$, Giacomo Dall'Olio ${ }^{1}$, \\ Lucrecia Pacheco Batista ${ }^{3}{ }^{(0)}$, Adeodato Ari Cavalcante Salviano ${ }^{4}$, Nazim S. Gruda ${ }^{5}$, \\ Francesco Orsini ${ }^{1, *(D)}$ and Giorgio Gianquinto ${ }^{1}$ (D) \\ 1 Department of Agricultural and Food Sciences (DISTAL), Alma Mater Studiorum University of Bologna, \\ Viale Fanin, 44, 40127 Bologna, Italy; nicola.michelon@unibo.it (N.M.); giuseppina.pennisi@unibo.it (G.P.); \\ giacomo.dallolio@alice.it (G.D.); giorgio.gianquinto@unibo.it (G.G.) \\ 2 Department of Soil and Water Management, Yezin Agriculture University, Yezin 15013, Myanmar; \\ dr.nangohnmyint@yau.edu.mm \\ 3 Department of Agriculture Sciences, Federal Rural University of Semi-arid, Mossorò-RN (UFERSA), \\ Rio Grande do Norte 59625-900, Brazil; lucreciapbatista@gmail.com \\ 4 Department of Agricultural Engineering and Soil, Federal University of Piauí (UFPI), \\ Teresina-Piauí 64049-550, Brazil; adeodatosalviano@hotmail.com \\ 5 Department of Horticultural Sciences, University of Bonn, INRES, 53113 Bonn, Germany; \\ ngruda@uni-bonn.de \\ * Correspondence: f.orsini@unibo.it; Tel.: +39-0512096677
}

Received: 14 August 2020; Accepted: 9 September 2020; Published: 12 September 2020

\begin{abstract}
Simplified soilless cultivation (SSC) systems have globally spread as growing solutions for low fertility soil regions, low availability of water irrigation, small areas and polluted environments. In the present study, four independent experiments were conducted for assessing the applicability of SSC in the northeast of Brazil (NE-Brazil) and the central dry zone of Myanmar (CDZ-Myanmar). In the first two experiments, the potentiality for lettuce crop production and water use efficiency (WUE) in an SSC system compared to traditional on-soil cultivation was addressed. Then, the definition of how main crop features (cultivar, nutrient solution concentration, system orientation and crop position) within the SSC system affect productivity was evidenced. The adoption of SSC improved yield $(+35 \%$ and $+72 \%$, in NE-Brazil and CDZ-Myanmar) and WUE (7.7 and 2.7 times higher, in NE-Brazil and CDZ-Myanmar) as compared to traditional on-soil cultivation. In NE-Brazil, an eastern orientation of the system enabled achievement of higher yield for some selected lettuce cultivars. Furthermore, in both the considered contexts, a lower concentration of the nutrient solution (1.2 vs. $\left.1.8 \mathrm{dS} \mathrm{m}^{-1}\right)$ and an upper plant position within the SSC system enabled achievement of higher yield and WUE. The experiments validate the applicability of SSC technologies for lettuce cultivation in tropical areas.
\end{abstract}

Keywords: urban agriculture; simplified soilless culture; hydroponics; conventional agriculture

\section{Introduction}

The detrimental effects of climate change are resulting in dramatic environmental, economic, and social consequences across the world [1]. Current projections show an overall increase in temperatures, with rainfall being irregularly distributed and characterized by heavy downpours [2-5]. Erratic climate can negatively affect natural resources availability (e.g., water and agricultural land), as well as posing severe risks on both ecosystems and human health [2,6]. Many developing 
countries, also located in tropical areas, are vulnerable to climate change due to their dependence on rain-fed agriculture, widespread poverty, and limited access to innovative technologies and improved agricultural practices [7]. An evident interdependence between climate change, economic vulnerability and migrations exists [8]. Accordingly, climate change is also resulting in a growing rate of migration toward urban and periurban areas of large cities. However, adaptation mechanisms are not yet in place, or are not strong enough, to mitigate the economic vulnerability of the most impoverished strata of the population [8]. Particularly in the tropical areas of Latin America and South-East Asia, health concerns are related to different forms of malnutrition frequently associated with a lack of micronutrients and vitamins in the population diet and low dietary diversification [9].

In Latin America, the Piaui State, located in the north-east area of Brazil (NE-Brazil), is one of the areas most affected by climate change due to its natural resources scarcity and extreme climatic conditions (i.e., semi-dry zone with a rainy season from December to May) [8]. Furthermore, after years of deforestation for agricultural purposes, the soil has a low amount of organic matter which negatively affects agricultural production [10]. Similar to Piaui State, the central dry zone in Myanmar (CDZ-Myanmar) is considered one of the most food-insecure regions of south-east Asia [11]. The climate of CDZ-Myanmar is characterized by a dry season without precipitation from November to March, which compromises and minimizes the agricultural choices of the farmers. Accordingly, climate and water scarcity are considered among the most significant problems of this area [12] and are expected to worsen in the future due to climate change [13].

In both NE-Brazil and CDZ-Myanmar, the introduction of innovative agricultural technologies which allow vegetable production even in urban and periurban areas, while fostering water-saving techniques to improve crop water use efficiency (WUE), is a crucial priority. According to Gianquinto et al. [14], it may be advisable to adopt simplified soilless cultivation (SSC) systems, which are independent of soil fertility and soil-borne diseases, do not require large spaces and intensive work labor and are characterized by high water and nutrient use efficiency thanks to the use of recirculating systems for the nutrient solution $[14,15]$. SSC systems are adapted from the concept of commercial hydroponics by integrating the advantages of easy construction and maintenance, while also reducing the initial economic investment or input requirements [16]. Different system designs exist for SSC, which mainly differ in the construction material, substrate used for plant growth and management of the nutrient solution [17].

The aim of this study is to assess the viability of an SSC system for the production of lettuce compared to traditional on-soil cultivation techniques in both NE-Brazil and CDZ-Myanmar, considering yield, water use efficiency and the overall physiological plant response. The assumption is that the adoption of SSC can increase yield and reduce water consumption of lettuce as compared to traditional on-soil grown plants also in very highly challenging contexts where soil quality is poor, climate is unfavorable and access to land by many people living in urban and periurban areas of large cities is limited. Moreover, the study integrates figures from different crop features and management strategies, such as crop positioning, garden orientation and cultivar traits to elaborate specific recommendations on the optimal management of the SSC systems proposed.

\section{Materials and Methods}

\subsection{Location}

North-East of Brazil (NE-Brazil): The experiments were carried out at the Horticulture Demonstration and Research Centre located at Fazenda Nova Esperança $\left(5^{\circ} 01^{\prime} \mathrm{S}\right.$ and $42^{\circ} 46^{\prime} \mathrm{W}$, $87 \mathrm{~m}$ a.s.l.), owned by the Foundation Pe. Antonio Dante Civiero, located on the outskirts of the city of Teresina, capital of Piaui. According to Köppen's classification, the local climate is Aw type, with a dry summer and a rainy season between January and May.

Central Dry Zone of Myanmar (CDZ-Myanmar): The experiments were conducted at the Soil and Water Research Station of Yezin Agriculture University (19 $83^{\prime} \mathrm{N}$ and $96^{\circ} 27^{\prime} \mathrm{E}, 122 \mathrm{~m}$ a.s.l.), 
located at the university campus in the periurban fringes of the capital NayPyiTaw. According to Köppen's classification, the local climate is Aw type, with a dry summer and a rainy season between June and October.

All experiments were carried out in the open field during the dry season, although the simplified soilless systems were equipped with a shading net (see description in Section 2.3).

\subsection{Experimental Design}

Four independent experiments were performed with commercial varieties of lettuce. In all experiments, lettuce (Lactuca sativa L.) was sown manually in 105 cells plastic seedling trays, and seedlings were transplanted 21 days after sowing (DAS).

- Experiment 1 (NE-Brazil): The trial considered a curly green lettuce (cv Isabela). Conventional on-soil cultivation and SSC system were compared. Plants were transplanted on 24 June 2009 and were harvested when reaching full maturity, which occurred at 40 and 31 days after transplanting (DAT) for traditional on-soil cultivation and in the SSC system, respectively. The experimental design was a strip block design with two treatments and three replicates.

- Experiment 2 (CDZ-Myanmar): The experiment was carried out with a curly green lettuce (cv Green wave). Conventional on-soil cultivation and SSC systems were compared. Plants were transplanted on 28 December 2018. Harvest occurred at 31 DAT in both systems. The experimental design was a completely randomized block design with two treatments and three replicates.

- Experiment 3 (NE-Brazil): Three green curly lettuce cultivars, namely cv Isabela, Veronica and Mimosa verde, and one red curly cultivar, namely cv Banchu Red Fire, were tested on their adaptability to the SSC system. The four cultivars were factorially combined with two different garden/plant row orientation (east and west exposure). Plants were transplanted on 18 July 2009. Harvest occurred at 31 DAT. The experimental design was a completely randomized block design with eight treatments and three replicates.

- Experiment 4 (CDZ-Myanmar): The experiment was carried out on two curly green lettuce cultivars, namely cv Green wave and Rapido 344. Plants were tested for their adaptability to SSC, and two different concentrations of nutrient solution salinity, characterized by an electrical conductivity (EC) of $1.2 \mathrm{dS} \mathrm{m}^{-1}\left(\mathrm{NS}_{1.2}\right)$ and E.C. $1.8 \mathrm{dS} \mathrm{m}^{-1}\left(\mathrm{NS}_{1.8}\right)$, were used. Moreover, the effect of plant growing position (upper position, UP vs lower position, LP) within the garden was evaluated. UP refers to the plant growing in the upper part of the SSC that receives the nutrient solution directly from the nutrient solution tank. LP refers to the plants growing in the lower part of the system, which get the nutrient solution drained from the upper part of the SSC system (Figure 1). Plants were transplanted on 19 February 2019 and were harvest at 31 DAT. The experimental design was a randomized block design with eight treatments and three replicates.

\subsection{Simplified Soilless Cultivation System}

The SSC system used was the so-called Bottles system (Figure 1), developed and tested in the northeast of Brazil since 2005 [18]. It is composed of a wooden/bamboo frame and a gravity-flow system, where nutrient solution drains from a tank of $310 \mathrm{~L}$ volume placed above the system at $2 \mathrm{~m}$ height. Hydraulic pipes with an emitter flow rate of $2 \mathrm{~L} \mathrm{~h}^{-1}$ direct the flux into the declined garden with a slope of $24 \%$, which is composed by connecting plastic drinking bottles that host both substrate (rice husk in all experiments) and plants. The excess nutrient solution is then directed through a drainage pipe system to another tank placed below. A 50\% shading net was placed above the system, to reduce light intensity. In NE-Brazil, the system used for the experiments was $6 \mathrm{~m}$ long and $3 \mathrm{~m}$ wide $\left(18 \mathrm{~m}^{2}\right)$ and accounted for 20 lines of $2 \mathrm{~L}$ plastic bottles $\left(8\right.$ bottles line $\left.\mathrm{e}^{-1}\right)$. Each bottle had two holes for hosting plants. Therefore, at full regime, the system could accommodate 320 plants. In CDZ-Myanmar, the system was tailored to the local context to meet the vegetables production needs of individual 
households. Accordingly, the system size was reduced ( $5 \mathrm{~m}$ long and $2 \mathrm{~m}$ wide, resulting in a garden surface of $\left.10 \mathrm{~m}^{2}\right)$, and a smaller tank for the nutrient solution (100 L) was adopted. Each module hosted 240 plants. When also considering the surrounding paths allowing for garden access (about half a meter on each side and in internal paths), the net planting density was of 26 plants $\mathrm{m}^{-2}$ in both NE-Brazil and CDZ-Myanmar.

In NE-Brazil, a nutrient solution $\left(\mathrm{NS}_{1.6}\right)$ previously adopted for local SSC cultivation was used $[18,19]$. The $\mathrm{NS}_{1.6}$ was prepared with locally available simple mineral salts and soluble fertilizers and was characterized by an electrical conductivity (EC) of $1.6 \mathrm{dS} \mathrm{m}^{-1}$ and a pH of 6.5. In CDZ-Myanmar, for both experiments, the NS was prepared by using locally available NPK fertilizer (15-15-15). During experiment 2, the adopted nutrient solution presented an EC of $1.2 \mathrm{dS} \mathrm{m}^{-1}$ and a $\mathrm{pH}$ of 7.7 , while in experiment 4 the nutrient solution was prepared at two concentrations, respectively, $0.6 \mathrm{~g} \mathrm{~L}^{-1}$ in $\mathrm{NS}_{1.2}$ $\left(\mathrm{EC}=1.2 \mathrm{dS} \mathrm{m}^{-1}, \mathrm{pH}=7.3\right)$ and $0.8 \mathrm{~g} \mathrm{~L}^{-1}$ in $\mathrm{NS}_{1.8}\left(\mathrm{EC}=1.8 \mathrm{dS} \mathrm{m}^{-1}, \mathrm{pH}=7.5\right)$.

Details on macronutrient and micronutrient concentrations of nutrient solutions are reported in Tables 1 and 2.

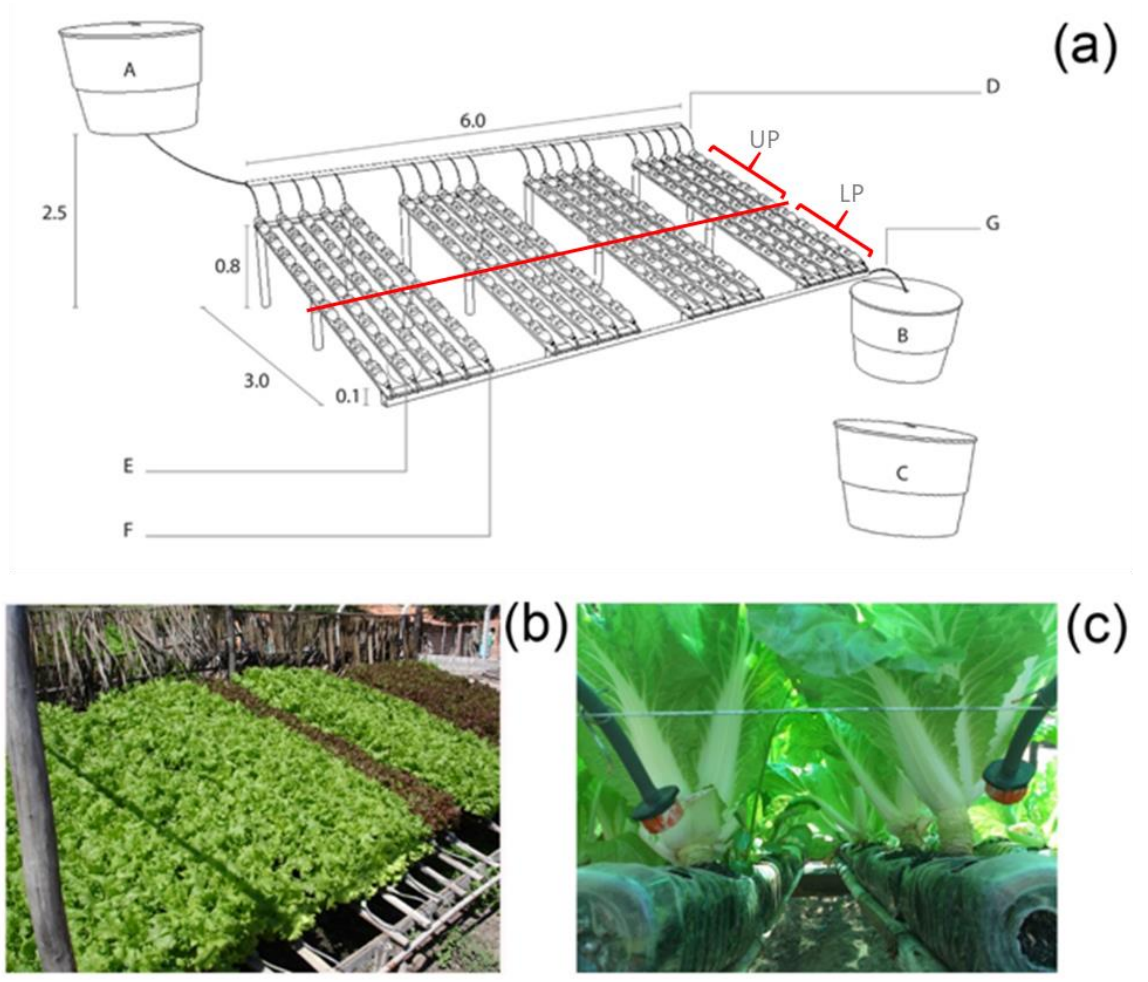

Figure 1. (a) Schematic drawing of the growing system used with measurements (in meters) adopted. The system includes a top (A) and a drainage (B) tank, as well as a fresh nutrient solution reservoir (C). The system is fitted with a gravity flow drip-irrigation system (D) that deliver the nutrient solution to 20 lines of recycled plastic bottles (E). Excess nutrient solution is then drained to a re-collection pipe (F) which is connected $(\mathrm{G})$ to the drainage tank $(\mathrm{B})$. UP = Upper position; LP = Lower position. Images of the systems in the cities of (b) Teresina (Piaui, Brazil) and (c) NayPyiTaw (Myanmar). 
Table 1. Macronutrient concentrations in water and nutrient solutions (NS) adopted in the experiments in NE-Brazil and in CDZ-Myanmar.

\begin{tabular}{|c|c|c|c|c|c|c|c|}
\hline & Exp. & $\begin{array}{c}\mathrm{N} \\
\left(\mathrm{mmol} \mathrm{L}^{-1}\right)\end{array}$ & $\begin{array}{c}\mathbf{P} \\
\left(\mathrm{mmol} \mathrm{L}^{-1}\right)\end{array}$ & $\begin{array}{c}\mathrm{K} \\
\left(\mathrm{mmol} \mathrm{L}^{-1}\right)\end{array}$ & $\begin{array}{c}\mathrm{S} \\
\left(\mathrm{mmol} \mathrm{L}^{-1}\right)\end{array}$ & $\begin{array}{c}\mathrm{Ca} \\
\left(\mathrm{mmol} \mathrm{L}^{-1}\right)\end{array}$ & $\begin{array}{c}\mathrm{Mg} \\
\left(\mathrm{mmol} \mathrm{L}^{-1}\right)\end{array}$ \\
\hline \multicolumn{8}{|c|}{ NE-Brazil } \\
\hline Water & 1,3 & 1.2 & nd & 0.6 & nd & 0.4 & 0.2 \\
\hline $\mathrm{NS}_{1.6}$ & 1,3 & 11.7 & 0.7 & 3.4 & 2.6 & 3.1 & 1.7 \\
\hline \multicolumn{8}{|c|}{ CDZ-Myanmar } \\
\hline Water & 2,4 & nd & nd & 0.05 & nd & 0.2 & 0.06 \\
\hline $\mathrm{NS}_{1.2}$ & 2,4 & 6.4 & 2.9 & 2.3 & 3.7 & 1.0 & 0.05 \\
\hline $\mathrm{NS}_{1.8}$ & 4 & 8.6 & 3.4 & 3.1 & 3.1 & 1.3 & 0.07 \\
\hline
\end{tabular}

Table 2. Micronutrient concentrations in water and nutrient solutions (NS) adopted in the experiments in NE-Brazil and in CDZ-Myanmar.

\begin{tabular}{|c|c|c|c|c|c|c|c|}
\hline & Exp. & $\begin{array}{c}\text { Fe } \\
\left(\mu \mathrm{mol} \mathrm{L} L^{-1}\right)\end{array}$ & $\begin{array}{c}\mathrm{Mn} \\
\left(\mu \mathrm{mol} \mathrm{L} \mathrm{L}^{-1}\right)\end{array}$ & $\begin{array}{c}\mathrm{Cu} \\
\left(\mu \mathrm{mol} \mathrm{L} \mathrm{L}^{-1}\right)\end{array}$ & $\underset{(\mu \mathrm{mol} \mathrm{L}}{\mathrm{Zn}}$ & $\begin{array}{c}\text { B } \\
\left(\mu \mathrm{mol} \mathrm{L} \mathrm{L}^{-1}\right)\end{array}$ & $\begin{array}{c}\text { Mo } \\
\left(\mu \mathrm{mol} \mathrm{L}^{-1}\right)\end{array}$ \\
\hline \multicolumn{8}{|c|}{ NE-Brazil } \\
\hline Water & 1,3 & nd & 0.5 & nd & 0.4 & 2.0 & nd \\
\hline $\mathrm{NS}_{1.6}$ & 1,3 & 26.9 & 12.4 & 1.6 & 4.6 & 21.5 & 0.5 \\
\hline \multicolumn{8}{|c|}{ CDZ-Myanmar } \\
\hline Water & 2,4 & 0.005 & 0.005 & nd & nd & nd & nd \\
\hline $\mathrm{NS}_{1.2}$ & 2,4 & 10.7 & 0.5 & 0.3 & 0.1 & nd & 0.01 \\
\hline $\mathrm{NS}_{1.8}$ & 4 & 14.3 & 0.7 & 0.4 & 0.13 & nd & 0.02 \\
\hline
\end{tabular}

nd $=$ not determined.

\subsection{Traditional on-Soil Cultivation}

The soil of the two regions had a loamy sand texture with similar hydrological soil parameters (wilting point and field capacity at $6 \% v: v$ and $13 \% v: v$, respectively). The physical and chemical characteristics of the soil in the two locations are described in Table 3. In both NE-Brazil and CDZ-Myanmar, the soil was overturned and dug with a hoe prior to cultivation. Soil fertilization provided a supply of $1.5 \mathrm{~kg} \mathrm{~m}^{-2}$ of cattle manure and $3.75 \mathrm{~g} \mathrm{~m}^{-2}$ of $\mathrm{N}, \mathrm{P}$, and $\mathrm{K}$ (mineral fertilizer 10-10-10 and Nitrophoska 15-15-15 in NE-Brazil and CDZ-Myanmar, respectively). Fertilizer was manually applied three days before transplanting. No additional fertilizer was applied during the crop cycles. Due to low soil $\mathrm{pH}$ in NE-Brazil, $0.15 \mathrm{~kg} \mathrm{~m}^{-2}$ of dolomitic limestone was added into the soil. The plots were raised by $20 \mathrm{~cm}$ and a trapezoid shape was developed, ensuring a base $1.2 \mathrm{~m}$ wide and a top $1.0 \mathrm{~m}$ wide. Finally, each plot was adjusted with a rake. Between the experimental plots, a space of approximately $0.7 \mathrm{~m}$ was left to facilitate maintenance, data collection and harvesting process. In both countries, plant spacing was $0.25 \mathrm{~m}$ between rows and $0.3 \mathrm{~m}$ within rows, resulting in a planting density of 13.3 plant $\mathrm{m}^{-2}$, according to the habits of the local farmers. The elemental unit consisted of a plot of $10 \mathrm{~m}^{2}$ (133 plants) or $5.4 \mathrm{~m}^{2}$ (72 plants) in NE-Brazil and CDZ-Myanmar, respectively.

Table 3. Chemical characterization of the soils in the two locations.

\begin{tabular}{|c|c|c|c|c|c|c|c|c|c|}
\hline \multirow{2}{*}{$\mathrm{OM}^{1}(\%)$} & \multirow{2}{*}{$\mathrm{pH}$} & \multirow{2}{*}{$\begin{array}{c}E C^{2} \\
\left(\mathrm{dS} \mathrm{m}^{-1}\right)\end{array}$} & \multicolumn{3}{|c|}{ Available } & \multicolumn{3}{|c|}{ Exchangeable } & \multirow{2}{*}{ 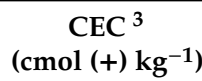 } \\
\hline & & & $\mathbf{N}$ & $\mathbf{P}$ & $\mathbf{K}$ & $\mathrm{Ca}$ & $\mathrm{Mg}$ & $\mathrm{Na}$ & \\
\hline \multicolumn{10}{|c|}{ NE-Brazil (Exp. 1) } \\
\hline 1.01 & 5.1 & nd & nd & 9.0 & 35.2 & 1.4 & 0.1 & 9.2 & 4.51 \\
\hline \multicolumn{10}{|c|}{ CDZ-Myanmar (Exp. 2) } \\
\hline 0.38 & 6.2 & 0.11 & 54 & 10.9 & 25 & 3.04 & 0.2 & 34.8 & nd \\
\hline
\end{tabular}

${ }^{1} \mathrm{OM}=$ Organic Matter ${ }^{2} \mathrm{EC}=$ Electrical Conductivity ${ }^{3} \mathrm{CEC}=$ Cation Exchange Capacity, nd = not determined. 


\subsection{Irrigation Management}

In the SSC system, nutrient solution flux started early in the morning (at 7:00 am) and continued until dusk (6:00 pm). Three times per day (at 7:00 am, 11:00 am, and 3:00 pm), the drained nutrient solution was moved back to the upper tank. The daily nutrient solution consumption was calculated by the difference between the nutrient solution volume between the upper tank (at the beginning of the day) and the bottom tank (at the end of the day). The nutrient solution in the system was refreshed every day by adding new nutrient solution to a set level

When plants were grown on the soil-based system, the irrigation management was different in NE-Brazil and CDZ-Myanmar experiments. In NE-Brazil, irrigation management was carried out based on the traditional local habit of the farmers by using manual irrigation. Water was distributed across experimental plots through manual labor, and a $12 \mathrm{~L}$ watering bucket was used. The amount of water distributed in a plot was based on farmers' experience. In CDZ-Myanmar, the irrigation management of soil-based treatments was based on crop evapotranspiration (ETc), restoring $100 \%$ of crop ETc by means of a drip irrigation system

ETc was calculated by using the following equation (Equation (1))

$$
\mathrm{ET}_{\mathrm{c}}=\mathrm{ET}_{0} \times \mathrm{K}_{\mathrm{c}}
$$

where $\mathrm{ET}_{\mathrm{c}}\left(\mathrm{mm} \mathrm{day}^{-1}\right)$ is the calculated crop evapotranspiration, $\mathrm{ET}_{0}\left(\mathrm{~mm} \mathrm{day}^{-1}\right)$ is the reference evapotranspiration, and $\mathrm{K}_{\mathrm{c}}$ is the FAO crop coefficient for lettuce [20].

For the estimation of the reference evapotranspiration $\left(\mathrm{ET}_{0}\right)$, the Hargreaves-Samani $(\mathrm{HS})$ equation (Equation (2)) was used,

$$
\mathrm{ET}_{0}=0.0023 \times\left(\mathrm{T}_{\text {mean }}+17.8\right) \times\left(\mathrm{T}_{\text {max }}-\mathrm{T}_{\text {min }}\right)^{0.5} \times \mathrm{R}_{\mathrm{a}}
$$

where $\mathrm{ET}_{0}\left(\mathrm{~mm} \mathrm{day}^{-1}\right)$ is the reference evapotranspiration rate, $\mathrm{T}_{\text {mean }}, \mathrm{T}_{\max }$ and $\mathrm{T}_{\min }$ are the mean, maximum and minimum temperature $\left({ }^{\circ} \mathrm{C}\right)$ of the day, respectively, and $\mathrm{R}_{\mathrm{a}}\left(\mathrm{W} \mathrm{m} \mathrm{m}^{-2}\right.$ day $\left.^{-1}\right)$ is the extraterrestrial solar radiation [20].

The meteorological data for the determination of the reference evapotranspiration were daily downloaded from the website of the Agro-Meteorological Department of Yezin Agriculture University (http://www.yau.edu.mm/), located inside the university campus, excluding extraterrestrial radiation Ra that was calculated according to Duffie and Beckman [21].

The amount of water used for each irrigation was calculated based on plant water balance considering soil properties, root depth, and climate data (including rainfall, if any). Daily ETc was estimated considering the FAO crop coefficient for lettuce crop growth stages. Lettuce cycles were divided into three growth stages, and the Kc used was 0.7, 1.0 and 0.95, respectively. The time of irrigation was determined when readily available soil water ( $50 \%$ available soil water) was depleted.

Sixteen mm diameter drip pipes were used. Drippers had a flow rate of approximately $1.3 \mathrm{~L} \mathrm{~h}^{-1}$, and each plant was supplied with a single dripper. A flow rate test and calculation of distribution uniformity (DU) were carried out before transplanting. The DU was calculated following the indications from Baum et al. [22]. Irrigation management (time and rate) was manually performed.

\subsection{Plant Measurements}

At harvest, plants were weighed to determine the fresh weight $\left(\mathrm{g} \mathrm{plant}^{-1}\right)$. Yield $\left(\mathrm{kg} \mathrm{m}^{-2}\right)$ was assessed by excluding external leaves which appeared damaged or wilted. Leaf number was also counted. Water use efficiency (WUE) was determined as the ratio between fresh weight and the volume of water used and was expressed as $\mathrm{g} \mathrm{FW} \mathrm{L} \mathrm{L}^{-1} \mathrm{H}_{2} \mathrm{O}$. In experiment 4, leaf stomatal conductance was also measured using a handheld photosynthesis measurement system model CI-340 (Camas, WA, USA), equipped with $6.25 \mathrm{~cm}^{2}$ cuvette. Measurements were made at 27 DAT on the upper surface of the canopy on three leaves per each plant from 10:00 to 14:00 taking approximately one hour to 
complete each replication. All plants were measured on a single day. In the system, EC and pH were constantly monitored using a Combo pH/EC/TDS/Temp tester Model HI98130 (HANNA ${ }^{\circledR}$, Villafranca Padovana (PD), Italy). In experiments 2 and 4, the nutrient solution temperature was also monitored twice a week.

\subsection{Statistical Analysis}

Data were collected on 12 plants from the central part of each plot. Data from experiments 1 and 2 were analyzed using one-way ANOVA. Data from experiments 3 and 4 were analyzed by using twoand three-way ANOVA, respectively. Means were separated using the Tukey HSD test at $p \leq 0.05$. Before the analysis, all data were checked for normality and homogeneity of variance. Averages and standard errors (SE) were calculated. Statistical analysis was carried out using R statistical software (version 3.3.2, package "emmeans" and "car").

\section{Results}

\subsection{Climate during the Experiments.}

\section{NE-Brazil}

During experiment 1, maximum air temperature ranged between 31.4 and $34.7^{\circ} \mathrm{C}$ with an average of $33.0^{\circ} \mathrm{C}$. Minimum temperature ranged between 17.8 and $22.4{ }^{\circ} \mathrm{C}$ with an average of $19.8^{\circ} \mathrm{C}$. The daily relative humidity $(\mathrm{RH})$ ranged between a minimum of $57 \%$ and a maximum of $97 \%$ (Table 4). Furthermore, $20.3 \mathrm{~mm}$ of effective rainfall occurred. During experiment 3, maximum air temperature ranged between 31.7 and $35.4{ }^{\circ} \mathrm{C}$ with an average maximum temperature of $34.0^{\circ} \mathrm{C}$. Minimum temperature ranged between 17.8 and $22.4^{\circ} \mathrm{C}$ with an average minimum temperature of $19.8^{\circ} \mathrm{C}$. The maximum relative humidity $(\mathrm{RH})$ was $97 \%$ and the minimum $\mathrm{RH}$ was $55 \%$ (Table 4 ). The growing degree days (GDD) from transplanting to harvest ranged from $710^{\circ} \mathrm{C}$ (experiment 3 ) to $920{ }^{\circ} \mathrm{C}$ (experiment 1$)$.

Table 4. Main climatic features during the experiments.

\begin{tabular}{|c|c|c|c|c|c|c|}
\hline \multicolumn{2}{|c|}{ Average Air Temperature $\left({ }^{\circ} \mathrm{C}\right)$} & \multicolumn{2}{|c|}{$\begin{array}{c}\mathrm{RH}^{1} \\
(\%)\end{array}$} & \multirow[t]{2}{*}{$\begin{array}{c}\text { DLI }^{2} \\
\left(\mathrm{~mol} \mathrm{~m}^{-2} \mathrm{~d}^{-1}\right)\end{array}$} & \multirow[t]{2}{*}{$\begin{array}{l}\text { Wind Speed } \\
\qquad\left(\mathrm{m} \mathrm{s}^{-1}\right)\end{array}$} & \multirow[t]{2}{*}{$\begin{array}{l}\mathrm{GDD}^{3} \\
\left({ }^{\circ} \mathrm{C}\right)\end{array}$} \\
\hline $\max$ & $\min$ & $\max$ & $\min$ & & & \\
\hline \multicolumn{7}{|c|}{ NE-Brazil (Exp. 1) } \\
\hline 33.0 & 19.8 & 97 & 57 & 24.3 & 0.9 & $920 * / 698 * *$ \\
\hline \multicolumn{7}{|c|}{ CDZ-Myanmar (Exp. 2) } \\
\hline 31.5 & 16.7 & 73 & 48 & 17.0 & 1.0 & 662 \\
\hline \multicolumn{7}{|c|}{ NE-Brazil (Exp. 3) } \\
\hline 34.0 & 19.8 & 97 & 55 & 24.7 & 1.0 & 710 \\
\hline \multicolumn{7}{|c|}{ CDZ-Myanmar (Exp. 4) } \\
\hline 35.6 & 19.5 & 59 & 30 & 20.9 & 1.9 & 731 \\
\hline
\end{tabular}

$1 \overline{\mathrm{RH}}=$ Relative Humidity $;{ }^{2} \mathrm{DLI}=$ average daily light integrals; ${ }^{3} \mathrm{GDD}=$ growing degree days, calculated based on a crop base temperature of $4{ }^{\circ} \mathrm{C}$ [23]; * on soil-based system (40 days cropping cycle); ${ }^{* *}$ on simplified soilless system (31 days crop cycle).

\section{CDZ-Myanmar}

During the experiment 2, maximum air temperature ranged between 25.0 and $34.0^{\circ} \mathrm{C}$ with an average of $31.5^{\circ} \mathrm{C}$. Minimum temperature ranged between 14.4 and $20.4{ }^{\circ} \mathrm{C}$, with an average of $16.7^{\circ} \mathrm{C}$. The daily relative humidity $(\mathrm{RH})$ ranged between a minimum of $48 \%$ and a maximum of $73 \%$ (Table 4 ). During experiment 4, maximum air temperature ranged between 30.7 and $38.6^{\circ} \mathrm{C}$ with an average maximum temperature of $35.6^{\circ} \mathrm{C}$. Minimum temperature ranged between 16.0 and $23.0^{\circ} \mathrm{C}$ with an average minimum temperature of $19.5^{\circ} \mathrm{C}$. The maximum relative humidity $(\mathrm{RH})$ was $59 \%$ and the 
minimum RH was $30 \%$. No rainfall occurred during the experiments. The growing degree days (GDD) from transplanting to harvest ranged from $662{ }^{\circ} \mathrm{C}$ (experiment 2) to $731^{\circ} \mathrm{C}$ (experiment 4) (Table 4).

\subsection{Experiment $1-N E$-Brazil}

Lettuce yield was higher ( $+35 \%)$ in the SSC system, with a mean value of $2.3 \mathrm{~kg} \mathrm{~m}^{-2}$, as compared to $1.7 \mathrm{~kg} \mathrm{~m}^{-2}$ achieved on soil (Figure 2a). This was mainly due to larger size of the leaves (data not shown), while leaf number was higher in plants grown on soil (Figure 2b). The increased yield was obtained with a daily water use $\left(\mathrm{L} \mathrm{m}^{-2} \mathrm{~d}^{-1}\right)$ approximately four times lower in the SSC system, as compared to conventional on-soil cultivation (1.8 vs. $7.5 \mathrm{~L} \mathrm{~m}^{-2} \mathrm{~d}^{-1}$ ) (data not shown). As a consequence, WUE in SSC system was 7.7 times higher, as compared to the conventional on-soil system, with mean values of 43.7 and $5.6 \mathrm{~g} \mathrm{~L}^{-1} \mathrm{H}_{2} \mathrm{O}$, respectively (Figure 2c).

\subsection{Experiment 2-CDZ-Myanmar}

During experiment 2 the average minimum temperature of the nutrient solution was $19.6 \pm 1.64^{\circ} \mathrm{C}$ while the average maximum temperature was $29.2 \pm 1.69^{\circ} \mathrm{C}$. The average $\mathrm{pH}$ was 7.7 , ranging from 7.4 to 8.1 . The average EC was 1.28 , ranging from 1.12 to $1.46 \mathrm{dS} \mathrm{m}^{-1}$.

Yield $\left(\mathrm{kg} \mathrm{m}^{-2}\right)$ was increased by $72 \%$ ( $\left.3.1 \mathrm{vs.} 1.8 \mathrm{~kg} \mathrm{~m}^{-2}\right)$ in SSC in comparison to the soil treatment (Figure 2d) and the leaf number was significantly higher in soil-grown lettuce compared to soilless-grown plants (Figure 2e). Daily water use $\left(\mathrm{L} \mathrm{m}^{-2} \mathrm{~d}^{-1}\right)$ was approximately two times lower in the SSC system $\left(2.66 \mathrm{~L} \mathrm{~m}^{-2} \mathrm{~d}^{-1}\right)$ as compared to conventional on soil production $\left(4.07 \mathrm{~L} \mathrm{~m}^{-2} \mathrm{~d}^{-1}\right)$. WUE in the SSC system was found to be 2.7 times higher than that obtained with conventional cultivation, with average values of 37.1 and $13.7 \mathrm{~g} \mathrm{~L}^{-1} \mathrm{H}_{2} \mathrm{O}$, respectively (Figure 2f).

\section{NE-Brazil}

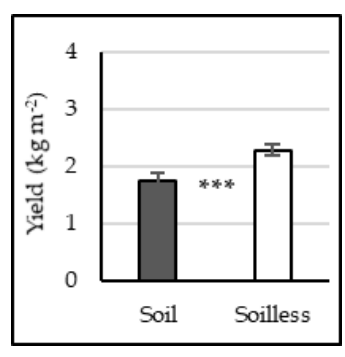

(a)

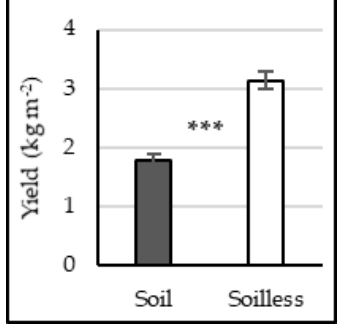

(d)

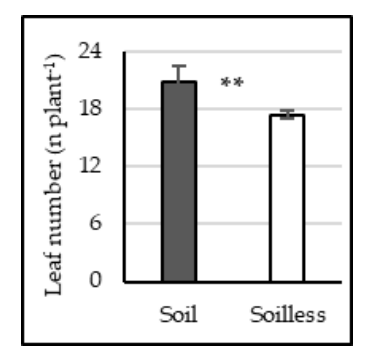

(b)

\section{CDZ-Myanmar}

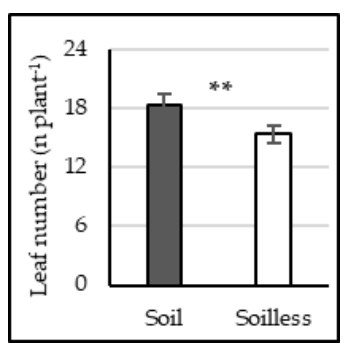

(e)

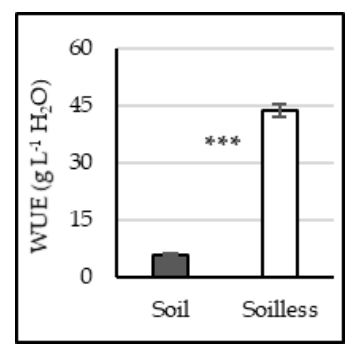

(c)

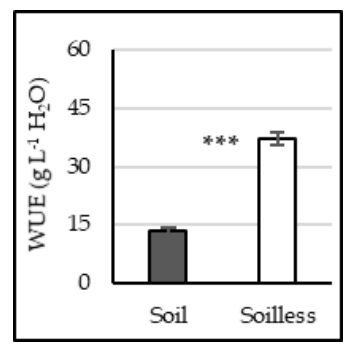

(f)

Figure 2. Results from experiments 1 (Brazil, top row) and 2 (Myanmar, bottom row). Lettuce yields $(\mathbf{a}, \mathbf{d})$, leaf number $(\mathbf{b}, \mathbf{e})$, and water use efficiency (WUE, $\mathbf{c}, \mathbf{f})$. Vertical bars represent standard errors. Significant differences at $\left.\left.p \leq 0.01{ }^{* *}\right), p \leq 0.001{ }^{* * *}\right)$. 


\subsection{Experiment 3-NE-Brazil}

Considering the system orientation, significant differences for yield were found only in Veronica and Banchu cultivars, for which the west-oriented system showed a reduction in yield of 10 and $44 \%$, respectively, as compared to the east-oriented one. In contrast, yields of cv Isabela and cv Mimosa were not affected by the SSC system orientation (Figure 3). Daily water use was about $1.8 \mathrm{~L} \mathrm{~m}^{-2} \mathrm{~d}^{-1}$, as for experiment 1 .

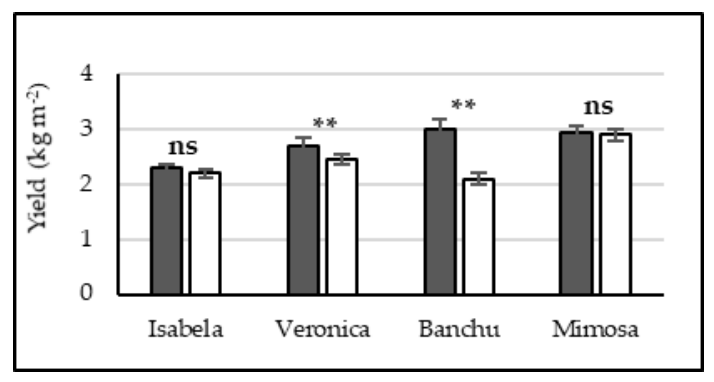

Figure 3. Results from experiments 3 (NE-Brazil). Yield response to the simplified soilless system orientation (east, grey columns; west, white columns) in four lettuce cultivars (Isabela, Veronica, Banchu, and Mimosa). Vertical bars represent standard errors. Significant differences at $p \leq 0.01\left({ }^{* *}\right), \mathrm{ns}=\operatorname{not}$ significant differences.

\subsection{Experiment 4-CDZ-Myanmar}

The average minimum temperature of the nutrient solution was $20.7 \pm 1.1^{\circ} \mathrm{C}$ while the average maximum temperature was $39.5 \pm 0.87^{\circ} \mathrm{C}$. Daily water use was $2.50 \mathrm{~L} \mathrm{~m}^{-2} \mathrm{~d}^{-1}$ for $\mathrm{NS}_{1.2}$ and $2.23 \mathrm{~L} \mathrm{~m}^{-2} \mathrm{~d}^{-1}$ for $\mathrm{NS}_{1.8}$. The average $\mathrm{pH}$ was 7.3 and 7.5 for $\mathrm{NS}_{1.2}$ and $\mathrm{NS}_{1.8}$, respectively. $\mathrm{pH}$ ranged from 6.4-8.7 for the former, and 6.6-8.9 for the latter. Average EC was 1.25 and $1.83 \mathrm{dS} \mathrm{m}^{-1}$ for $\mathrm{NS}_{1.2}$ and $\mathrm{NS}_{1.8}$, respectively, ranging from $1.14-1.48 \mathrm{dS} \mathrm{m}^{-1}$ for solution $\mathrm{NS}_{1.2}$ and $1.59-2.06 \mathrm{dS} \mathrm{m}^{-1}$ for solution $\mathrm{NS}_{1.8}$ (data not shown). Results of analysis of variance in Table 5 show that the EC of the nutrient solution (EC), lettuce cultivar $(\mathrm{Cv})$, and plants position $(\mathrm{P})$ significantly affected plant morphological and productive parameters, as well as WUE and the crop physiological response.

Table 5. Results from the ANOVA on experiment 4 (CDZ-Myanmar). Effect of EC of the nutrient solution (EC), cultivar (Cv), and position within the garden $(\mathrm{P})$ on lettuce yield, leaf number, and water use efficiency (WUE). Significant differences at $p \leq 0.05\left(^{*}\right), p \leq 0.01\left(^{* *}\right)$ and $p \leq 0.001\left(^{* * *}\right)$, ns $=$ not significant differences.

\begin{tabular}{|c|c|c|c|c|}
\hline & $\begin{array}{c}\text { Yield } \\
\left(\mathrm{kg} \mathrm{m}^{-2}\right)\end{array}$ & $\begin{array}{l}\text { Leaf Number } \\
\left.\text { (n plant }{ }^{-1}\right)\end{array}$ & $\underset{\left(\mathrm{mmol} \mathrm{m} \mathrm{m}^{-2} \mathrm{~s}^{-1}\right)}{\mathrm{g}_{\mathrm{s}}}$ & $\begin{array}{l}\text { WUE } \\
\left(\mathrm{g} \mathrm{L}^{-1}\right)\end{array}$ \\
\hline EC of nutrient solution (EC) & $* * *$ & $* * *$ & $* * *$ & $* * *$ \\
\hline Cultivar $(\mathrm{Cv})$ & $* *$ & $* * *$ & $* * *$ & $*$ \\
\hline Position $(\mathrm{P})$ & $* * *$ & ns & $* * *$ & $* * *$ \\
\hline $\mathrm{EC} \times \mathrm{Cv}$ & $*$ & $* *$ & $* *$ & $*$ \\
\hline $\mathrm{EC} \times \mathrm{P}$ & $* * *$ & * & $* *$ & $* * *$ \\
\hline $\mathrm{Cv} \times \mathrm{P}$ & ns & ns & ns & ns \\
\hline $\mathrm{EC} \times \mathrm{Cv} \times \mathrm{P}$ & $* *$ & $\mathrm{~ns}$ & $*$ & $* *$ \\
\hline
\end{tabular}

Yield, stomatal conductance and WUE were affected by EC, CV, and $\mathrm{P}$-wherein a significant interaction between the three factors was noted-while leaf number was only affected by EC and $\mathrm{CV}$, with a significant interaction between the two factors (Table 5). Yield of plants placed in the lower position (LP) was not affected by $\mathrm{Cv}$ and $\mathrm{EC}$, while for both cultivars the plants in the upper position (UP) yielded more when $\mathrm{NS}_{1.2}$ was used (Table 6). The yield of plants belonging to cv Thai and grown by using $\mathrm{NS}_{1.2}$ was four times higher, as compared to yield of Thai lettuce supplied with $\mathrm{NS}_{1.8}$ 
and placed in the same position within the system (Table 6). The increased yield was mainly due to leaf number, as Thai plant grown adopting $\mathrm{NS}_{1.2}$ showed the highest number of leaves (12.9 leaves plant $^{-1}$ ) while no differences were observed between the other treatments (data not shown). Stomatal conductance was highest $\left(212 \mathrm{mmol} \mathrm{m}^{-2} \mathrm{~s}^{-1}\right)$ in Thai lettuce grown on the upper part of the system by using $\mathrm{NS}_{1.2}$ (Table 6). For plants grown in the lower part of the system (LP), stomatal conductance was only affected by $\mathrm{CV}$, and was higher in $\mathrm{cv}$ Thai for both considered EC (Table 6). Leaf temperature was only affected by the position $(\mathrm{P})$ in the system (data not shown), and was lowest in plants grown on the top of the system $\left(28.8^{\circ} \mathrm{C}\right.$ compared to $29.8^{\circ} \mathrm{C}$ measured in plants grown at the bottom of the system). In cv Thai, WUE was highest in plants fed with $\mathrm{NS}_{1.2}$ and grown in the upper position (UP) of the system, while for cultivar Rapido 344 the only statistically significant difference was evidenced between plants grown on the upper position and fed with $\mathrm{NS}_{1.2}$ and plants grown in the lower position of the system and fed with $\mathrm{NS}_{1.8}$ (Table 6).

Table 6. Results from experiment 4 (CDZ-Myanmar). Effects of factorial combination of EC of the nutrient solution (EC, 1.2 vs. $1.8 \mathrm{dS} \mathrm{m}^{-1}$ ), cultivar (Cv, Thai vs $\mathrm{EW}$ ) and position (P, upper position, UP vs lower position, LP) within the garden on lettuce yield, stomatal conductance $\left(\mathrm{g}_{\mathrm{s}}\right)$ and water use efficiency (WUE). Different letters indicate significant differences at $p \leq 0.05$.

\begin{tabular}{|c|c|c|c|c|c|c|c|}
\hline \multirow{3}{*}{$\frac{E C}{\left(\mathrm{dS} \mathrm{m}^{-1}\right)}$} & \multirow{3}{*}{ Cultivar } & \multirow{2}{*}{\multicolumn{2}{|c|}{$\begin{array}{c}\text { Yield } \\
\left(\mathrm{kg} \mathrm{m}^{-2}\right)\end{array}$}} & \multicolumn{2}{|c|}{$\mathrm{g}_{\mathrm{s}}$} & \multicolumn{2}{|c|}{ WUE } \\
\hline & & & & \multicolumn{2}{|c|}{$\left(\mathrm{mmol} \mathrm{m} \mathrm{m}^{-2} \mathrm{~s}^{-1}\right)$} & \multicolumn{2}{|c|}{$\left(\mathrm{g} \mathrm{L}^{-1} \mathrm{H}_{2} \mathrm{O}\right)$} \\
\hline & & UP & LP & UP & LP & UP & LP \\
\hline 1.2 & Thai & $2.88(\mathrm{a})$ & $1.18(\mathrm{bc})$ & 212 (a) & $118(b)$ & $38.4(\mathrm{a})$ & $15.7(b c)$ \\
\hline 1.2 & Rapido 344 & $1.79(\mathrm{~b})$ & $1.14(\mathrm{c})$ & $100(\mathrm{~b})$ & 44 (de) & $24.0(\mathrm{~b})$ & $15.2(\mathrm{bc})$ \\
\hline 1.8 & Thai & $0.71(\mathrm{c})$ & $0.65(\mathrm{c})$ & $121(\mathrm{~b})$ & $91(\mathrm{bc})$ & $10.57(\mathrm{c})$ & $9.71(\mathrm{c})$ \\
\hline 1.8 & Rapido 344 & $0.82(\mathrm{c})$ & $0.57(\mathrm{c})$ & $78(\mathrm{c})$ & $35(\mathrm{e})$ & $12.3(\mathrm{c})$ & $8.54(\mathrm{c})$ \\
\hline
\end{tabular}

\section{Discussion}

The application of different cropping systems significantly affected yield, physiological response and water use efficiency of lettuce grown in both NE-Brazil and CDZ-Myanmar.

Water availability is one of the major constraints for agricultural development and food production. The first and second experiments aimed to determinate whether SSC lettuce production is a suitable and sustainable alternative to conventional on-soil production in both locations. Barbosa et al. [23], when comparing commercial (high-tech) hydroponic greenhouses against on-soil lettuce production, found that hydroponics could increase yield by 11 -folds, thanks to improved nutrition and environmental control. According to our results obtained in both experiments, the use of a simplified (low tech) soilless system allowed increase in the yield of lettuce but to a lesser extent $(+35 \%$ in NE-Brazil and $+72 \%$ in CDZ-Myanmar, (Figure $2 \mathrm{a}, \mathrm{d})$ ). Yield increase can be the result of higher planting density (26 vs. 13 plants $\mathrm{m}^{-2}$, on SSC and on-soil cultivation respectively), fast plant growth and precocity of production (31 vs 40 DAT according to experiment 1 ) and the improved environmental conditions maintained within the SSC system, including plant nutrition, uniform and constant irrigation, as well as the shading cover integrated in the SSC system. According to Zhao et al., the adoption of a shading net as a cover for lettuce production in the summer season in Kansas led to a slightly lower daily maximum air temperature relative to the open field, with an average reduction of $\approx 0.4{ }^{\circ} \mathrm{C}$ [24]. Moreover, Zhao et al. reported that the shading net has a significant impact on soil temperature and leaf temperature [24]. Indeed, in comparison with open field conditions, when shading net is adopted, a considerable reduction of leaf surface temperature, by 1.5 to $2.5^{\circ} \mathrm{C}$, was observed [24], thus affecting the plants' capacity to absorb water and nutrients [25]. In the SSC system, the higher fertigation frequency probably affected production capacity. Silber et al. experimented on the effect of fertigation frequency on yield, water and nutrient uptake of lettuce [26], finding that high fertigation frequency (from 2 to 10 events a day) induced a significant increase (13-15\%) in lettuce fresh weight (FW) [26]. 
Furthermore, SSC systems are also considered water-saving technologies, thanks to the capability to deliver water directly to the plant root $[27,28]$. Despite limited soil exploration by the shallow rooting system of lettuce, in NE-Brazil, when a conventional growing system was adopted, irrigation water was applied by means of a bucket or can on the entire soil surface and consequently a significant amount of water is lost through evaporation and percolation into the sandy soil. Increase in the use of low-flow and more targeted irrigation techniques, such as the adoption of a drip irrigation system, could lower the overall water use of conventional farming [23]. As a matter of fact, drip irrigation was used as a control treatment in the CDZ-Myanmar experiments. Accordingly, the adoption of an SSC system enabled a reduction of water use by $76 \%$ and $59 \%$ in NE-Brazil and in CDZ-Myanmar, respectively, as compared to on-soil production. The observed water savings are consistent with previous literature, e.g., when a SSC system was adopted in Colombia, water use was reduced by $90 \%$ as compared to the traditional on-soil cropping system [29].

A consequence of higher yield and lower water use was an increased WUE in the SSC systems. In NE-Brazil and CDZ-Myanmar, WUE was, respectively, 7.7 and 2.7-fold higher, as compared to conventional on-soil production (Figure 2c,f). Similarly, WUE for lettuce in hydroponics was previously found in the range of $2.9 \mathrm{~g}$ of dry mass per $\mathrm{L}^{-1} \mathrm{H}_{2} \mathrm{O}$ [30], or $41 \mathrm{~g}$ of fresh mass per $\mathrm{L}^{-1} \mathrm{H}_{2} \mathrm{O}$ [31]. Lettuce grown in high-tech hydroponic conditions showed a reduction in water use by 13-fold, as compared with traditional on-soil cultivation [23]. Under the expected climate change scenarios and water limitation for agriculture, SSC systems could be a valuable strategy to sustain highly productive agriculture where the adoption of high-technology systems is not affordable $[3,5,28,32]$.

In the third experiment, the adaptability of four lettuce cultivars to two different garden orientations was addressed to have a deeper understanding of the SSC system management. It emerged that the response of plant growth to the garden orientation was cultivar dependent (Figure 3). Accordingly, Veronica and Banchu achieved a higher yield with the eastern garden exposure (Figure 3), which received a lower amount of solar radiation in the afternoon mitigating the high air temperatures. Wheeler et al. [33] indicated $23^{\circ} \mathrm{C}$ as the optimal daily temperature for growing lettuce, a condition that is far below the mean temperatures observed in NE-Brazil during the experiment. Heat stress could also result in a greater osmotic stress caused by the nutrient solution, resulting in lower water uptake and reduced plant growth [27]. Moreover, due to elevated temperatures in the root zone environment, hypoxia may occur, inhibiting root respiration, mineral uptake and water movement into the roots [34].

In the fourth experiment, the growth response of plants grown in different positions within the system was addressed as a function of both plant cultivar and the nutrient solution concentration (Table 5). Accordingly, the highest yield was associated with Thai cultivar supplied with $\mathrm{NS}_{1.2}$ (Table 6). Possibly, under the local climate, plants preferred a nutrient solution with lower EC, and the Thai cultivar better responded to reduced osmotic stress. Furthermore, yield was the highest when Thai cultivar was grown in the upper part of the system. (Table 6). As reported by Gianquinto et al. [14], this aspect could be due to the increased temperature reached by the nutrient solution during the flow between the top and the bottom tank. It would suggest that by the time the nutrient solution reached the lower section of the SSC, it was significantly warmed up by irradiance in the plastic bottles, although this statement should further be confirmed by determination of nutrient solution and substrate temperatures in the different positions. Thompson et al. [35] showed that a $24{ }^{\circ} \mathrm{C}$ root temperature in hydroponic systems is the ideal temperature whereby lettuce growth can be maximized, even with elevated air temperature. Different studies also reported that high nutrient solution temperature depresses water and nutrient uptake through reduced oxygen availability, also affecting physiological processes such as root browning and active transport in membranes [36]. Moreover, it was also observed that high solution temperature might decrease nutrient concentration (particularly of $\mathrm{N}, \mathrm{K}$ and $\mathrm{Ca}$ ) in the root, which may ultimately decrease crop growth [25]. It should be further studied, however, whether this may be associated with increased nutrient solution temperature as water flows through the system, or with selective absorption of specific nutrients from those plants that receive the 
nutrient solution first. In this regard, it could also be considered to add additional hydraulic pipes with emitters in the middle of the system.

\section{Conclusions}

The study addressed the application of SSC technologies [37-39] for lettuce production in tropical wet and dry climates. Elevated potentialities, in terms of both yield increase and improved water use efficiency in comparison with traditional on-soil cultivation technologies, were evidenced in both locations. Furthermore, the study explored alternative crop management strategies evidencing differences in cultivar adaptability and potential productivity. For instance, garden orientation was shown to affect crop productivity on a cultivar-dependent basis. Finally, under the elevated temperatures that are locally experienced, it is advisable to reduce the concentration of the nutrient solution (with EC of $1.2 \mathrm{dS} \mathrm{m}^{-1}$ providing better results than EC of $1.8 \mathrm{dS} \mathrm{m}^{-1}$ ). Interestingly, the yield was also improved when plants were located in the upper positions of the garden. Government and local support services could influence the future of soilless farming, as subsidies could be used to offset the relatively high initial cost of SSC infrastructure. We conclude that a simplified soilless system could become one of the efficient strategies for contributing to sustainably feeding the world's growing population, especially in challenging areas such as the north east of Brazil and the central dry zone of Myanmar.

Author Contributions: Conceptualization, N.M., A.A.C.S., F.O., G.G.; methodology, N.M.; validation, N.M., G.G., G.P., F.O.; formal analysis, N.M., G.P., G.G.; investigation, N.M., L.P.B., G.D., N.O.M.; resources, F.O., G.P.; data curation, N.M., G.P.; writing—original draft preparation, N.M.; writing—review and editing, G.P., G.G., F.O., N.S.G.; visualization, N.M., G.P., G.G.; supervision, F.O., G.P.; project administration, N.M.; funding acquisition, F.O., G.G. All authors have read and agreed to the published version of the manuscript.

Funding: This research received no external funding.

Acknowledgments: We thank Padre Humberto Pietrogrande, former President of Pe. Antonio Dante Civiero Foundation, Nang Hseng Hom, Rector of Yezin agriculture University of Myanmar and Terre des Hommes Italia INGO for providing the area, infracture and equipment to carry out the experiments.

Conflicts of Interest: The authors declare no conflict of interest.

\section{References}

1. Eileen, E.B. Impact of Climate Change and Local Adaptation Strategies of Various Socio-economic Groups in Isabela, Northern Philliphines. Clim. Issue 2009, 22, RN15.

2. Bisbis, M.B.N.; Gruda, M. Blanke 2018: Potential impacts of climate change on vegetable production and product quality-A review. J. Clean. Prod. 2018, 170, 1602-1620. [CrossRef]

3. Gruda, N.; Bisbis, M.B.; Tanny, J. Impacts of protected vegetable cultivation on climate change and adaptation strategies for cleaner production-A review. J. Clean. Prod. 2019, 225, 324-339. [CrossRef]

4. Audu, E.B. Gas Flaring: A Catalyst to Global Warming in Nigeria. Int. J. Sci. Technol. 2013, 3, 6-10.

5. Gruda, N.; Bisbis, M.B.; Tanny, J. Influence of climate change on protected cultivation: Impacts and sustainable adaptation strategies-A review. J. Clean. Prod. 2019, 225, 481-495. [CrossRef]

6. Intergovernmental Panel on Climate Change (IPCC). Climate Change: Impacts, Adaptation and Vulnerability. In Exit Epa Disclaimer Contribution of Working Group II for the Fourth Assessment Report of the Intergovernmental Panel on Climate Change; Cambridge University Press: Cambridge, UK, 2007.

7. Dowuona Nii Nortey, M.; Kwaghe, P.V.; Abdulsalam, B.; Aliyu, H.S.; Dahiru, B. Review of Farm Level Adaptation Strategies to Climate Change in Africa. Greener J. Agron. For. Hortic. 2014, 2, 038-043.

8. Barbieri, A.F.; Domingues, E.; Queiroz, B.L.; Ruiz, R.M.; Rigotti, J.I.; Carvalho, J.A.; Resende, M.F. Climate change and population migration in Brazil's Northeast: Scenarios for 2025-2050. Popul. Environ. 2010, 31, 344-370. [CrossRef]

9. Orsini, F.; Kahane, R.; Nono-Womdim, R.; Gianquinto, G. Urban agriculture in the developing world: A review. Agron. Sustain. Dev. 2013, 33, 695-720. [CrossRef] 
10. Souza, E.D.; Carneiro, M.A.C.; Paulino, H.B.; Silva, C.A. Frações do carbono orgânico, biomassa e atividade microbiana em um Latossolo Vermelho sob cerrado submetido a diferentes sistemas de manejos e usos do solo. Acta Sci. Agron. 2006, 28, 323-329. [CrossRef]

11. Cho, A.; Tun Oo, A.; Speelman, S. Assessment of household food security through crop diversification in Natmauk township, Magway Region, Myanmar. In Proceedings of the Tropentag 2016: Solidarity in a Competing World: Fair Use of Resource, Vienna, Austria, 18-21 September 2016; pp. 1-5.

12. Pavelic, P.; Sellamuttu, S.S.; Johnston, R.; McCartney, M.; Sotoukee, T.; Balasubramanya, S.; Latt, K. Integrated Assessment of Groundwater Use for Improving Livelihoods in the Dry Zone of Myanmar; International Water Management Institute (IWMI): Colombo, Sri Lanka, 2015; Volume 164.

13. Aoki, Y. A Problem of Climate Change as Seen by a Pharmaceutical Researcher. J. Health Sci. 2009, 55, 857-859. [CrossRef]

14. Gianquinto, G.; Orsini, F.; Michelon, N.; da Silva, D.F.; De Faria, F.D. Improving yield of vegetables by using soilless micro-garden technologies in peri-urban area of north-east Brazil. Acta Hortic. 2007, 747, 57-65. [CrossRef]

15. Savvas, D.; Gruda, N. Application of soilless culture technologies in the modern greenhouse industry-A review. Eur. J. Hortic. Sci. 2018, 83, 280-293. [CrossRef]

16. Orsini, F.; Morbello, M.; Fecondini, M.; Gianquinto, G. Hydroponic gardens: Undertaking malnutrition and poverty through vegetable production in the suburbs of Lima, Peru. Acta Hortic. 2010, 881, 173. [CrossRef]

17. Izquierdo, J. Simplified hydroponics: A tool for food security in Latin America and the Caribbean. Acta Hortic. 2007, 742, 67-74. [CrossRef]

18. Gianquinto, G.; Michelon, N.; Orsini, F. Idroponia in un'area povera del nord est del Brasile. In Un Esempio di Cooperazione Decentrata: Simplified Soilless Cultivation in a Marginal Area of North-East Brazil: An Example of Decentralised Cooperation; Franceschetti, G., CLEUP. Regione Veneto-FAO, Eds.; Agricoltura e Ruralità nei Paesi ad Economia Povera: Padova, Italy, 2006; pp. 95-106.

19. Rodríguez-Delfín, A.; Hoyos, M.; Chang, M. Soluciones Nutritivas en Hidroponía: Formulación y Preparación; Centro de Investigación de Hidroponía y Nutrición Mineral, Universidad Nacional Agraria La Molina: Lima, Peru, 2001; p. 100.

20. Trajkovic, S. Hargreaves versus Penman-Monteith under humid conditions. J. Irrig. Drain. Eng. 2007, 133, 38-42. [CrossRef]

21. Duffie, J.A.; Beckman, W.A.; Blair, N. Solar Engineering of Thermal Processes, Photovoltaics and Wind, 5th ed.; John Wiley \& Sons: Hoboken, NJ, USA, 2020.

22. Baum, M.C.; Michael, D.D.; Grady, L.M. Analysis of residential irrigation distribution uniformity. J. Irrig. Drain. Eng. 2005, 131, 336-341. [CrossRef]

23. Barbosa, G.L.; Gadelha, F.D.A.; Kublik, N.; Proctor, A.; Reichelm, L.; Weissinger, E.; Halden, R.U. Comparison of Land, Water, and Energy Requirements of Lettuce Grown Using Hydroponic vs. Conventional Agricultural Methods. Int. J. Environ. Res. Public Health 2015, 12, 6879-6891. [CrossRef]

24. Zhao, X.; Carey, E.E. Summer production of lettuce, and microclimate in high tunnel and open field plots in Kansas. HortTechnology 2009, 19, 113-119. [CrossRef]

25. Falah, M.A.F.; Wajima, T.; Yasutake, D.; Sago, Y.; Kitano, M. Responses of root uptake to high temperature of tomato plants (Lycopersicon esculentum Mill.) in soil-less culture. J. Agric. Sci. Technol. 2010, 6, 543-558.

26. Silber, A.; Xu, G.; Levkovitch, I.; Soriano, S.; Bilu, A.; Wallach, R. High fertigation frequency: The effects on uptake of nutrients, water and plant growth. Plant Soil. 2003, 253, 467-477. [CrossRef]

27. Sanchez, S.V. Avaliação de Alface Crespa Produzidas em Hidropônia Tipo NFT em Dois Ambientes Protegidos em Ribeirão Preto (SP); Paulista State University, College of Agricultural and Veterinary Science: Sao Paulo, Brazil, 2007; Available online: http://depositorio.unesp.br/handle/11449/96944 (accessed on 12 August 2020).

28. Gruda, N.S. Increasing Sustainability of Growing Media Constituents and Stand-Alone Substrates in Soilless Culture Systems. Agronomy 2019, 9, 298. [CrossRef]

29. Bradley, P.; Marulanda, C. Simplified hydroponics to reduce global hunger. Acta Hortic. 2000, 554, $289-296$. [CrossRef]

30. Wheeler, R.M.; Sager, J.C.; Berry, W.L.; Mackowiak, C.L.; Stutte, G.W.; Yorio, N.C.; Ruffe, L.M. Nutrient, acid and water budgets of hydroponically grown crops. Acta Hortic. 1997, 481, 655-662. [CrossRef] 
31. Michelon, N.; Pennisi, G.; Myint, N.O.; Orsini, F.; Gianquinto, G. Strategies for Improved Water Use Efficiency (WUE) of Field-Grown Lettuce (Lactuca sativa L.) under a Semi-Arid Climate. Agronomy 2020, 10, 668. [CrossRef]

32. Martínez-Alvarez, V.; Soto-García, M.; Maestre-Valero, J.F. Hydroponic system and desalinated seawater as an alternative farm-productive proposal in water scarcity areas: Energy and greenhouse gas emissions analysis of lettuce production in southeast Spain. J. Clean. Prod. 2018, 172, 1298-1310. [CrossRef]

33. Wheeler, T.R.; Hadley, P.; Morison, J.I.L.; Ellis, H. Effects of temperature on the growth of lettuce (Lactuca sativa L.) and the implications of assessing the impacts of potential climate changes. Eur. J. Agron. 1993, 2, 305-311. [CrossRef]

34. Ehret, D.L.; Edwards, D.; Helmer, T.; Lin, W.; Jones, G.; Dorais, M.; Papadopoulos, A.P. Effects of oxygen-enriched nutrient solution on greenhouse cucumber and pepper production. Sci. Hortic. 2010, 125, 602-607. [CrossRef]

35. Thompson, H.C.; Langhans, R.W.; Both, A.J.; Albright, L.D. Shoot and root temperature effects on lettuce growth in a floating hydroponic system. J. Am. Soc. Hortic. Sci. 1998, 123, 361-364. [CrossRef]

36. Trejo-Téllez, L.I.; Gómez-Merino, F.C. Nutrient solutions for hydroponic systems. In Hydroponics-A Standard Methodology for Plant Biological Researches; Martinez-Mate, M.A., Martin-Gorriz, B., Eds.; InTechOpen: Rijeka, Croatia, 2012; pp. 1-22.

37. Fecondini, M.; Damasio De Faria, A.C.; Michelon, N.; Mezzetti, M.; Orsini, F.; Gianquinto, G. Learning the value of gardening: Results from an experience of community based simplified hydroponics in north-east Brazil. Acta Hort. 2010, 881, 111-116. [CrossRef]

38. Fecondini, M.; Casati, M.; Dimech, M.; Michelon, N.; Orsini, F.; Gianquinto, G. Improved cultivation of lettuce with a low cost soilless system in indigent areas of northeast brazil. Acta Hort. 2009, 807, 501-507. [CrossRef]

39. Orsini, F.; Michelon, N.; Scocozza, F.; Gianquinto, G. Farmers-To-Consumers Pipeline: An Associative Example of Sustainable Soil-Less Horticulture in Urban And Peri-Urban Areas. Acta Hort. 2009, 809, $209-220$. [CrossRef]

(C) 2020 by the authors. Licensee MDPI, Basel, Switzerland. This article is an open access article distributed under the terms and conditions of the Creative Commons Attribution (CC BY) license (http://creativecommons.org/licenses/by/4.0/). 